\title{
En mann i 60-årene som uventet og dramatisk forsøker selvmord
}

\author{
En tidligere psykisk frisk mann i 60-årene ble i løpet av noen måneder \\ deprimert, angstfylt og bekymret for somatisk sykdom. Ved innleggelse \\ i psykiatrisk klinikk gjorde han et uventet og dramatisk selvmordsfors øk. \\ Under en lang innleggelse og senere poliklinisk oppfølging har årsaken \\ til selvmordsforsøket vært et tilbakevendende tema.
}

\author{
Marianne Holm \\ marianne.holm@sthf.no \\ Seksjon for alderspsykiatri \\ Sykehuset Telemark
}

\begin{abstract}
En mann i 60-årene kom til akuttime ved psykiatrisk klinikk pga. økende psykisk uro. Han beskrev angst, søvnløshet og skjelvinger. Han fortalte at han var redd for å ta en overdose medikamenter for å slippe unna den påtrengende uroen. Medikamenter som var blitt forsøkt for søvn, var zopiklon, levomepromazin og klometiazol. Han var bekymret for sykdom knyttet til hjertet og magen. Han fremsto som ordnet, og det var ikke mistanke om psykotiske symptomer.

Pasienten var gift og hadde vært svært aktiv i yrkes-og samfunnsliv. Han hadde ingen kjent psykisk sykdom fra tidligere, men mor og et søsken hadde hatt depressive plager. Han hadde kjent paroksystisk atrieflimmer. De siste tre månedene hadde han vært innlagt flere ganger ved medisinsk avdeling pga. mage- og brystsmerter. I samme tidsrom døde en slektning av kreft. Pasienten besøkte vedkommende i terminalfasen. Under innleggelsene ble det funnet atrieflimmer og gastroduodenitt og videre somatiske undersøkelser ble planlagt. Pasienten trodde han hadde kreft og virket angstpreget og deprimert. Det ble ikke foretatt en psykiatrisk vurdering. Ved siste innleggelse seks dager før det aktuelle ble han satt på sertralin, et antidepressivt legemiddel. Pasient og pårørende mener at de ikke fikk informasjon om dette.
\end{abstract}

I akuttimen ved psykiatrisk klinikk ble han vurdert som svært angstpreget, og første tiltak var bedring av søvn. I tillegg ble det lagt opp til tett oppfølging med tanke på forhøyet selvmordsrisiko. Sertralindosen ble økt fra $50 \mathrm{mg}$ til $100 \mathrm{mg}$. Han fikk nitrazepam for søvn samt en forsiktig dose olanzapin. Tentativ diagnose var alvorlig depresjon. Særlig uttalte symptomer var angst og tvangspregede tanker.

Omtrent én måned senere ble han innlagt for øyeblikkelig hjelp ved psykiatrisk klinikk etter at han var blitt raskt verre med økende angst, skjelvinger og intens tinnitus. Ved innkomst var han orientert for tid, sted og situasjon og uten sikre psykotiske symptomer. Han var angstfylt, redd for kreft og katastrofer og opptatt av slektningen som nylig var død. Det ble vurdert ikke å være forhøyet selvmordsrisiko. Sertralin ble seponert, olanzapin ble økt og han startet med venlafaksin.

Om morgenen fire døgn senere ble han funnet blodig etter selvpåførte dype kutt tvers over halsen og på ventralsiden av det ene håndleddet. Larynx var nærmest overskåret og det var sene- og nerveskader $i$ håndleddet. Pasienten var rolig og bevisst og ble fraktet til akuttmedisinsk mottak og videre til Rikshospitalet.

Etter retur fra Rikshospitalet til intensivavdelingen fikk han psykiatrisk tilsyn. Han fremsto ukonsentrert og mimikkfattig og hadde vansker med å gjøre rede for det som hadde skjedd. Han uttrykte at han en stund hadde hatt tanker om å gjøre det slutt og beskrev disse nærmest som tvangstanker. Han nevnte tinnitus som mulig utløsende årsak og beskrev en følelse av tristhet, uro og håpløshet.

På intensivavdelingen ble pasienten vurdert som alvorlig deprimert med angst og tvangstanker samt forhøyet selvmordsrisiko. Man mistenkte en alvorlig sinnslidelse og det ble opprettet tvungen observasjon etter lov om psykisk helsevern. Det synes særlig å være selvmordsfaren som veide tungt $i$ helhetsvurderingen. Han fikk tett oppfølging av psykiatrisk personale og ble raskt overført til psykiatrisk akuttseksjon.

Pasientens tilstand forverret seg ytterligere $i$ ukene som fulgte. Venlafaksindosen ble økt. Han var svært nedstemt, fikk klare forfølgelsestanker og nektet etter hvert å ta imot medisiner, delvis også mat. Det ble fattet tvangsbehandlingsvedtak og pasienten fikk zuklopentiksolinjeksjoner. Elektrostimulerende behandling ble foreslått, men avslått av pasient og pårørende. Venlafaksin ble seponert og etter $c a$. to måneder uten antidepressiver startet man med klomipramin. 
På CT caput ble det funnet noe romslige plassforhold frontalt. Enfotonstomografi viste redusert aktivitet bilateralt frontoorbitalt, og på EEG fant man lettgradig generalisert dysrytmi uten epileptogen aktivitet. $\mathrm{Pa}$ sienten ble vurdert av nevrolog som fant at han var parkinsonistisk preget, mest sannsynlig pga. antipsykotika. Det ble gjort enkel kognitiv screening der pasienten var lite motivert og man ikke kunne konkludere. I notat fra øre-nese-hals-lege fremkommer at han hadde vært plaget med tinnitus i lang tid, men at det hadde forverret seg betydelig de seneste månedene for så å bedres litt.

Pasienten hadde nå vært innlagt i fem måneder. Diagnose og behandling ble drøftet på ny. Behandlere og pårørende var enige om at det var en alvorlig depressiv tilstand med angst og vrangforestillinger. Ut ifra bildediagnostiske funn ble det diskutert om det kunne være hjerneorganiske forhold av betydning. Man ønsket en grundigere nevropsykologisk undersøkelse når pasienten ble i stand til å medvirke. Pasienten hadde ingen opplevelse av at medisinene han hadde forsøkt hadde hjulpet. Kona mente at de gjorde han verre. Han var ikke blitt bedre i løpet av ukene da han nektet å ta antidepressiver.

Pasienten ble overført til seksjon for alderspsykiatri for videre behandling og mer aktiv miljøterapeutisk tilnærming. Han sto på dette tidspunktet på klomipramin og zuklopentiksol.

Pasienten var $i$ tiden rundt overføringen stort sett sengeliggende, ofte med ansiktet mot veggen, fåmælt, ekstremt angstfylt og opptatt av kroppslige symptomer.

Medikamentell antidepressiv behandling hadde åpenbart ikke hatt effekt, og det kunne ikke utelukkes at den hadde medvirket til forverring. Klomipramin ble seponert. Personalet skulle forsøke forsiktig aktivisering selv om pasienten motsatte seg det meste. Undertegnede skulle ha hyppige samtaler selv om responsen var sparsom.

De neste fire ukene fremsto tilstanden som relativt uendret. En ettermiddag fikk han lette, forbigående brystsmerter. Uten at personalet observerte det, forlot han avdelingen og gikk til elven. Han returnerte gjennomvåt og fortalte at han hadde villet drukne seg, men stoppet idet han skulle ta skrittet ut på dypet. Selvmordsrisikoen ble da vurdert som så høy at han måtte tilbakeføres til akuttseksjonen.

Under oppholdet på akuttseksjonen sa han ja til elektrostimulerende behandling og fikk $i$ alt 16 behandlinger. Han ble noe kvikkere motorisk, men var like trist, og behandlingen ble avsluttet. Det hadde samtidig vært forsøkt et nytt antidepressivt legemiddel (duloksetin) i fem uker. Også denne behandlingen ble avsluttet.

Ved retur til alderspsykiatrisk seksjon hadde pasienten vært innlagt $i$ åtte måneder. Han virket mer apatisk enn trist, lå fortsatt mye og var lite nøye med personlig hygiene og atferd.

I samarbeidsmøte med pårørende ble den alvorlige og langvarige tilstanden igjen drøftet. Verken ulike antidepressiver, antipsykotika, elektrostimulerende behandling, samtaler med psykiater, kompetent miljøterapeutisk oppfølging eller pårørendes hyppige besøk hadde hjulpet. Situasjonen syntes fastlåst. Vi tok opp igjen de bildediagnostiske funnene samt tegnene til ukritiskhet og ventilerte muligheten for frontal degenerasjon. Fremtidsutsiktene ble brakt på banen og sykehjem ble nevnt, til ektefellens forskrekkelse. Vi ble imidlertid enige om ikke å gi oss ennå, prøve med hjemmebesøk med følge av personale og gjøre et medikamentforsøk med litium.

Litiumbehandling ble startet. Etter en uke kom de første små tegnene til bedring. Pasienten hadde en helg uten angst, møtte til måltider og stelte seg på eget initiativ. Han kom i gang med behandling hos privat psykomotorisk fysioterapeut og fikk støttekontakt som han gikk lange turer med. Fortsatt var han imidlertid $i$ mange måneder preget av passivitet og rigiditet både mentalt og kroppslig. Pleiepersonalet hadde en møysommelig jobb med å få han til å medvirke aktivt i daglige gjøremål. Tempoet i tiltakene måtte hele tiden nøye avstemmes med pasientens ønsker, samtidig som han måtte puffes videre. Kognitiv testing med vekt pà eksekutivfunksjoner viste redusert abstraksjonsevne, problemløsningsevne og mental fleksibilitet. Nevropsykologen konkluderte med at funnene ikke var markante og kunne skyldes den psykiske lidelsen. Testingen ble begrenset av dårlig motivasjon.

Sakte, men sikkert steg stemningsleiet, og egendriven til aktivitet økte. Pasienten dro på overnattingspermisjoner og fotballkamper og gjenopptok kontakten med gamle venner.

Ved utskrivning nesten to àr etter innleggelse var han i tilnærmet normalt stemningsleie, uten angst og gledet seg til å gjenoppta sitt gamle liv.

Utskrivningen var nøye planlagt i samråd med pasient og pårørende. Han ble vurdert å være i remisjon av sin alvorlige depresjon, men anbefalt å fortsette med litium og å unngå antidepressiver ved en eventuell ny depresjon. Han takket ja til dagtilbud og poliklinisk oppfølging ved alderspsykiatrisk seksjon. Han ønsket ingen tiltak i primær- helsetjenesten utover kontakt med fastlege og støttekontakt. Selvmordsfaren ble vurdert å være lav, men ved residiv av depresjon, angst eller søvnproblemer måtte man raskt være oppmerksom på økt fare.

Pasienten er blitt fulgt halvårlig i fem år etter utskrivning. Han har gjenopptatt sitt gamle liv med familie, venner, fysisk aktivitet og reiser til utlandet. Han har vært utsatt for påkjenninger med egen somatisk sykdom (hjertesykdom, stenting, elektrokonvertering, ablasjonl samt dødsfall $i$ vennekretsen. Han beskrev lett nedstemthet da han en periode sto på metoprolol. Ellers har han tålt belastningene godt.

I de polikliniske samtalene har han reflektert mye over sin langvarige sykdomsperiode, selvmordsforsøkene og behandlingen. Han opplever å ha kommet styrket ut av hendelsene og har ønsket å bidra med håp til andre om at det går an å bli frisk selv om den psykiske sykdommen er alvorlig og langvarig. Pasienten har gjentatte ganger snakket om hva som ledet til det første selvmordsforsøket. Han beskriver at to uker etter sertralinstart fikk han svært plagsom tinnitus og en følelse av at angsten som var der fra før, ble mye verre. Likevel hadde han kontroll over tanker og atferd frem til innleggelsen da han fikk sine første doser venlafaksin. Han forteller at han noen timer etter inntaket (den fjerde kvelden) plutselig fikk tanken: «Er det noen vits å leve lenger?». Han bruker ordene «totalt forandret, fraværende og helt frakoblet». Når det gjelder det andre selvmordsforsøket, opplevde han foranledningen helt annerledes. Han forteller at brystsmertene hadde gitt ham angst og at han forlot avdelingen med en plan om å gå til elven for å drukne seg. Han beskriver en a-ha-opplevelse da han sto til knes $i$ det kalde vannet: «Hva er det du driver med?». Hans egen opplevelse er at fra da av snudde det og gikk bedre. Vi så ingen bedring før flere måneder senere.

Pasienten er fortsatt frisk. Hans og konas tanker rundt antidepressiver har vært til ettertanke og medvirkende til at kasuistikken ble skrevet.

\section{Diskusjon}

Pasienten illustrerte et langt og komplisert sykdomsforløp hos en tidligere psykisk frisk mann. Diagnosen alvorlig depressiv episode ble stilt raskt, og han fikk tett poliklinisk oppfølging og innleggelse da angsten økte. Det ble gitt antidepressiv, angstdempende og antipsykotisk behandling og senere $\mathrm{i}$ forløpet elektrostimulerende behandling. Trass i to selvmordsforsøk, hvorav ett meget dramatisk, og nesten to års innleggelse kom han seg og har vært psykisk frisk i fem år. Redusert aktivitet frontoorbitalt påvist på enfo- 


\section{RAMME 1}

\section{Selvmordsrisiko ved antidepressiver (6)}

- Behandling med antidepressiver kan være forbundet med økt forekomst av selvmordstanker og selvmordsforsøk, særlig i de første ukene.

- Pasienter, pårørende og fastlege må være klar over den økte risikoen for selvmordstanker og selvmordsfors øk.

- Ved økt uro, agitasjon og påtrengende selvmordstanker må det nøye vurderes om det antidepressive legemidlet kan være årsak til forverringen.

tonstomografi var sannsynligvis relatert til depresjon og ikke hjerneorganisk sykdom (1). CT-funn med romslige plassforhold frontalt kan være en normalvariasjon. Han har ingen kognitive problemer i dag.

Pasient og pårørende var opptatt av å forstå det første dramatiske selvmordsforsøket som de mente ble forårsaket av antidepressiver. De fastholdt at ingen antidepressive legemidler hjalp og at tilstanden snarere ble forverret. Behandlingsapparatet delte synet på manglende eller negativ effekt av antidepressiver. Han ble dårligere på sertralin og enda dårligere da dosen ble økt. Venlafaksin ga samme resultat. Vi så en sammenheng mellom bruk av antidepressiver og selvmordsforsøket uten at vi i en komplisert sykehistorie kan si at det er årsaken. I ettertid så vi at energimengden gitt under elektrostimulerende behandling ikke var optimal og at behandlingen ikke var godt nok kvalitetssikret. Klinisk bedring kunne knyttes til introduksjon av litium. Vår vurdering er at litium burde vært forsøkt tidligere. Etter litiumstart ble pasienten mer tilgjengelig for miljøterapeutiske tiltak, samtaler og psykomotorisk fysioterapi. Mest sannsynlig var det mange faktorer som bidro samtidig til at tilstanden bedret seg.

Det er kjent forhøyet risiko for selvmord hos personer med alvorlige depresjoner (2, 3), også hos eldre (4). Antidepressive legemidlers rolle som risikofaktor for selvmordsatferd har vært omstridt og diskuteres av Vaaler \& Fasmer i en kronikk i Tidsskriftet nylig (5). Medikamentene frarådes brukt til barn og ungdom pga. mulig økt risiko for selvmordsatferd (3).

I nasjonale retningslinjer for diagnostisering og behandling av voksne med depresjon står det at man ikke har funnet holdepunkter for forverring av selvmordsrisiko under behandling med antidepressiver (6).

Vår pasient ble behandlet med litium med god effekt. Litium er vist å kunne redusere selvmord og selvmordsforsøk ved stemningslidelser (7).

Selv om metaanalyser har vist redusert risiko for selvmord under behandling med antidepressiver, har det $\mathrm{i}$ årtier vært publisert enkeltstudier og kasuistikker (8) som beskriver en sammenheng mellom start av antidepressiver, særlig selektive serotoninreopptakshemmere og venlafaksin, og selvmordsatferd og voldelige selvmord. Medikamentutløst akatisi og agitasjon nevnes som to av flere mulige forklaringer på sammenhengen. Studiene har noen svakheter, men man har villet avdekke om det finnes en sårbar gruppe pasienter som reagerer idiosynkratisk på disse legemidlene. Mange forfattere understreker at hos eldre utgjør underbehandling av depresjon sannsynligvis en større fare (8).

Ut ifra en helhetsvurdering vil det hos de fleste pasienter med en alvorlig depressiv tilstand være indikasjon på behandling med et antidepressivt legemiddel. Imidlertid er det all grunn til å gjenta forsiktighetsregelen fra de nasjonale depresjonsretningslinjene (ramme 1): «Behandling med antidepressiver kan være forbundet med økt forekomst av selvmordstanker og selvmordsforsøk, særlig i de første ukene. Pasientene bør informeres om dette og om at de straks bør kontakte lege dersom de skulle oppleve økt uro, agitasjon eller påtrengende selvmordstanker» (6). I så fall må ansvarlig lege nøye revurdere behandlingen. Det bør vurderes om årsaken til forverringen er forbundet med lav dose av antidepressiver eller om pasienten fikk adekvat dose i adekvat tid, men har manglende terapirespons? Manglende effekt av antidepressiver er et stort problem. Eller kan medikamentet ha forverret tilstanden slik at det må seponeres? Særlig hos pasienter med høyt lidelsestrykk og selvmordstanker er det avgjørende at legen er klar over denne mulige årsaken og handler deretter.
Kasuistikken viser viktigheten av hele tiden å evaluere behandlingen når responsen ikke er som forventet. Ikke bare behandlernes vurderinger, men også de som pasienten og de pårørende gjør, må inngå i evalueringen. Ettersom korte behandlingsløp er i tiden, viser kasuistikken at noen ganger er en lang sykehusinnleggelse både nødvendig og nyttig.

Pasient og pårørende har gitt samtykke til at artikkelen blir publisert.

Jeg takker kolleger for verdifulle innspill.

\section{Marianne Holm (f. 1959)}

er spesialist i psykiatri, seksjonsoverlege og har alderspsykiatri som fordypningsområde. Forfatter har fylt ut ICMJE-skjemaet og oppgir ingen interessekonflikter.

\section{Litteratur}

1. Amen DG, Trujillo M, Newberg A et al. Brain SPECT imaging in complex psychiatric cases: An evidence-based, underutilized tool. Open Neuroimaging J 2011; 5: 40-8.

2. Maris RW. Suicide. Lancet 2002; 360: 319-26.

3. Friedman RA, Leon AC. Expanding the black box depression, antidepressants, and the risk of suicide. N Engl J Med 2007; 356: 2343-6.

4. Conwell Y, Duberstein PR, Caine ED. Risk factors for suicide in later life. Biol Psychiatry 2002; 52: 193-204

5. Vaaler AE, Fasmer OB. Antidepressive legemidler - klinisk praksis må endres. Tidsskr Nor Legeforen 2013; 133: 428-30

6. Nasjonal retningslinje for diagnostisering og behandling av voksne med depresjon i primær-og spesialisthelsetjenesten. Oslo: Helsedirektoratet 2009. http://helsedirektoratet.no/publikasjoner/ nasjonale-retningslinjer-for-diagnostisering-ogbehandling-av-voksne-med-depresjon-i-primerog-spesialisthelsetjenesten/Sider/default.aspx (26.11.2014).

7. Nasjonal faglig retningslinje for forebygging av selvmord i psykisk helsevern. Oslo: Helsedirektoratet, 2008. www.helsedirektoratet.no/publikasjoner/ nasjonal-faglig-retningslinje-for-forebygging-avselvmord-i-psykisk-helsevern/Sider/default.aspx (26.11.2014).

8. Reeves RR, Ladner ME. Antidepressant-induced suicidality: an update. CNS Neurosci Ther 2010; $16: 227-34$

Mottatt 11.6. 2014, første revisjon innsendt 15.10. 2014, godkjent 26.11. 2014. Redaktør: Tor Rosness. 